\title{
Angioses in the equine endometrium - Pathogenesis and clinical correlations
}

\author{
Doris Schoon, H.-A. Schoon and E. Klug* \\ Institut für Veterinär-Pathologie der Universität Leipzig; *Klinik für Pferde der Tierärztlichen Hochschule Hannover
}

\begin{abstract}
Summary
Angioses in the equine endometrium are detectable in varying quality and quantity in nearly $80 \%$ of broodmares. Only younger maiden mares have intact vessels, older maiden mares show a mostly mild sclerosis within the intima and the adventitia. In multiparous mares the alterations affect all layers of the vessel walls and resemble the so called „pregnancy sclerosis“ in other species. The incidence and degree increases with the number of foals delivered, independent of the age of the mare. At least two factors, age and parity, have to be considered as possible causes for degenerative angiopathies. There seems to be no obviously direct but an indirect negative effect on fertility of the mare, because angioses result in a reduced endometrial perfusion and drainage and the alterations are intimately related to endometrosis. Angioses should be taken into consideration when classifying endometria with a view to prognosis. A relationship between endometrial angioses and extrauterine vascular lesions, possibly leading to fatal hemorrhages during late pregnancy or at foaling and occurring mainly in older mares, is supposed.
\end{abstract}

Keywords: $\quad$ horse, endometrial angioses, pathogenesis, fertility, endometrosis

\section{Angiosen im Endometrium der Stute - Pathogenese und klinische Korrelationen}

Angiosen kommen im Endometrium der Zuchtstute, qualitativ und quantitativ variabel, mit einer Inzidenz von 80\% vor. Ausschließlich junge Maidenstuten weisen intakte Gefäße auf, Intima- und Perisklerosen dominieren das Bild bei älteren Maidenstuten. Die Gefäßalterationen multiparer Stuten betreffen alle Schichten der Wand und ähneln der bei anderen Tierarten beschriebenen Graviditätssklerose. Die Häufigkeit und der Schweregrad der Angiosen nimmt mit der Anzahl der Abfohlungen zu, unabhängig vom Alter der Stute. Es handelt sich ätiopathogenetisch gesehen um alters-, vor allem jedoch um trächtigkeitsassoziierte Veränderungen. Angiosen sind in mehrfacher Hinsicht von prognostischer Bedeutung: sie scheinen, besonders in einem vorgeschädigten Endometrium, einen additiv negativen Effekt auf die Fertilität der Stute zu haben, führen zu Lymphdrainage- und Perfusionsstörungen und sind eng assoziiert mit dem Vorkommen einer Endometrose. Daher sollten sie bei der prognostischen Bewertung von Endometriumbiopsien Berücksichtigung finden. Eine Beziehung zwischen endometrialen Angiosen und gleichartigen Veränderungen der großen extrauterinen Gefäße, und damit eine Disposition für fatale Gefäßrupturen, die bei älteren Stuten im Verlaufe der fortgeschrittenen Trächtigkeit oder während der Geburt vorkommen, wird vermutet.

Schlüsselwörter: Pferd, endometriale Angiosen, Pathogenese, Fertilität, Endometrose

\section{Introduction}

The endometrium is composed of epithelial (luminal epithelium and uterine glands), stromal and vascular elements. There are numerous reports dealing with inflammatory and degenerative processes of the epithelial and stromal compartments and their significance to fertility in the mare. By contrast only very little information is available about equine endometrial vascular alterations first described by Constantinescou (1921). In human beings, cattle, pigs and rodents the negative effects of vascular lesions on fertility are clearly documented (Rahima and Soderwall, 1977; Hard and Anderson, 1982; Roperto and Galati, 1983; Goswamy et al., 1988).

\section{Incidence}

In routine investigations of endometrial biopsies degenerative angiopathies varying in quality and quantity are present in more than $80 \%$ (Schoon et al., 1997). They mainly occur as a mild to moderate increase of collagen and elastic fib- res within the arterial or venous walls, severe and destructive lesions are observed more seldom. Moderate to severe lesions are obvious in veins $(24.68 \%$ to $51.3 \%)$, in arterioles (43\% to $59.9 \%)$ and in arteries $(61.8 \%$ to $69.4 \%)$ of the cases investigated (Kriesten, 1995; Grüninger, 1996). Angioses are found uniformly distributed within the whole endometrium (Runge, 1995).

Absolutely intact vessels occur in younger maiden mares only. In older maiden mares mild periscleroses may be present. Vessel lesions of multipara are characterised by a fibroelastosis of the intima, the media and the adventitia. The incidence and degree increase with the number of previous foalings. Additionally there is an obvious relationship between angioses, age and barrenness (Schoon et al., 1997). The incidence of severe angioses decreases with the time interval to the last foaling. This phenomen however, is obvious only in mares younger than 17 years. This is interpreted as indicative for a regeneration capacity of the vessels, which is reduced in aged mares. 


\section{Morphology}

The vascular lesions are visible by lightmicroscopy: moderate and severe angioses, even with $\mathrm{HE}$ staining only (Schoon et al., 1994); discrete ones become obvious in special stainings (i.e. van Gieson-elastica and Picro-Sirius Red stain) and TEM respectively (Grüninger, 1996).

Degenerative changes in arterial and venous vessels include elastosis, fibrosis and fibroelastosis of the vessel wall as well as perivascular fibrosis and calcification processes. In arteries and arterioles an elastosis of the internal elastic membrane, a fibroelastosis of the tunica media and an atrophy of myocytes are the main findings (Fig. 1). In veins a fibroelastosis of the tunica media dominates. In arterial as well as venous vessels these mural lesions are commonly associated with perifibrotic and perifibroelastotic alterations. Mineralisation processes are restricted to arterial vessels and occur nearly exclusively in the course of moderate to severe vascular alterations.

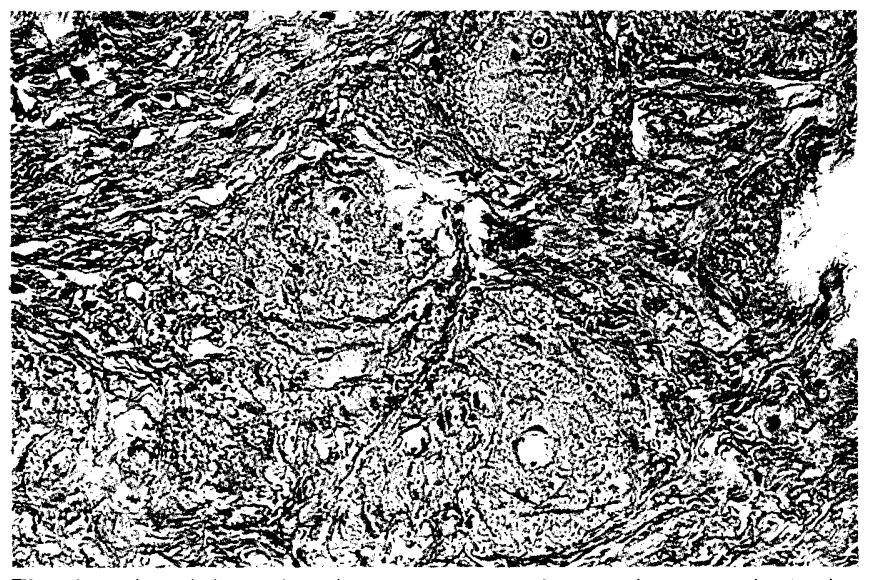

Fig. 1: Arterioles showing a severe destructive panelastosis. Numerous elastic fibres are visible within all layers of the vessel wall. Myocytes are atrophic. The lumina are nearly completely obstructed. Endometrial biopsy from a 19 year-old mare, 11 foalings. Picro-Sirius Red stain, $\times 300$

Arteriole mit einer hochgradigen Panelastose. Massenhaft elastische Fasern befinden sich in allen Gefäßwandschichten. Die Myozyten sind atrophisch, die Lumina fast vollständig verlegt. Endometriumbiopsie einer 19 Jahre alten Stute, 11 Abfohlungen. Pikro-Sirius Rot-Färbung, Gerätevergrößerung 300x

\section{Pathogenesis}

The pathogenesis of endometrial angioses in the mare is discussed controversially. Oikawa et al. (1993) postulate that degenerative processes occur as a reinforcement of the vessel wall to compensate for its decreased vascular resistance to mechanical stress. Further studies hypothesise that decreased vascular resistance is due to an age related development of medial atrophy (Nambo et al., 1994, 1995). These investigations are based only on very few old mares and no consideration is given to the number of previous foalings. However, other authors clearly demonstrate that the frequency of moderate to severe degenerative angiopathies increases with the number of foals delivered (Kriesten et al., 1996; Schoon et al., 1997; Grüninger et al., 1998).
Age-related vascular lesions are reported as a fibrosis and elastosis mainly occurring in the intima and adventitia of vessels in pigs, hamsters and mares (Bal and Getty, 1973, Rahima and Soderwall, 1977; Kriesten et al., 1996; Grüninger et al., 1998). Pregnancy sclerosis, however, is a condition affecting all layers of the vessels as described in innumerable studies and in various species. It is likely that at least the two factors, age and parity, have to be considered with a view to pathogenesis of endometrial vascular degeneration, because naturally the number of foalings is related to age.

Comparing mares of similar age but differing in the numbers of previous foalings the relation between angiosis and parity is obvious (Kriesten, 1995; Wrede, 1999). For example in a group of thirteen to seventeen year-old mares investigated (Fig. 2) mild angiopathies occur only in uniparous animals and the frequency of moderate to severe changes increases with the number of foalings.

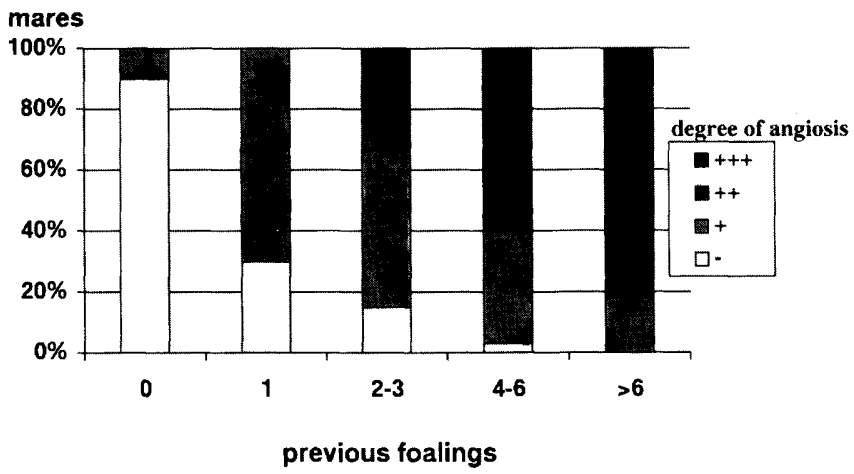

Fig. 2: Relative incidence and degree of angioses in relation to the number of previous foalings in 13 to 17 year-old mares $(n=93)$.

$-=$ negative $+=$ mild $;++=$ moderate $;+++=$ severe

Vorkommen und Grad von Angiosen in Abhängigkeit von der Anzahl bisheriger Abfohlungen bei Stuten im Alter von 13 bis 17 Jahren $(n=93)$.

- = keine Angiose $++=$ geringgradig, $++=$ mittelgradig, $+++=$ hochgradig

Besides quantity, the quality of the alterations is influenced by the number of foalings as well (Fig. 3). After the first partus (Fig. 3-A) a mild fibroelastosis is obvious. The membrana elastica interna is enlarged. The peripheral media is thickened by deposition of collagen fibres arranged in bundles and several elastic fibres occur.

After the third partus (Fig. 3-B) the membrana elastica interna is irregularly arranged and rich in mature elastic fibres. The media still appears concentric but the myocytes have irregular contours and are intermingled with elastic fibres.

After fifteen foalings (Fig. 3-C) the whole vessel wall is enlarged by an accumulation of irregularly arranged, partially degenerated and mineralised fibres. The remaining myocytes are often degenerated, atrophic or crippled with numerous intracytoplasmatic matrix vesicles. Mucopolysaccharides are stored beneath the endothelium. In those multiparous mares a severe destructive fibroelastosis has developed affecting arterial and venous vessels. 


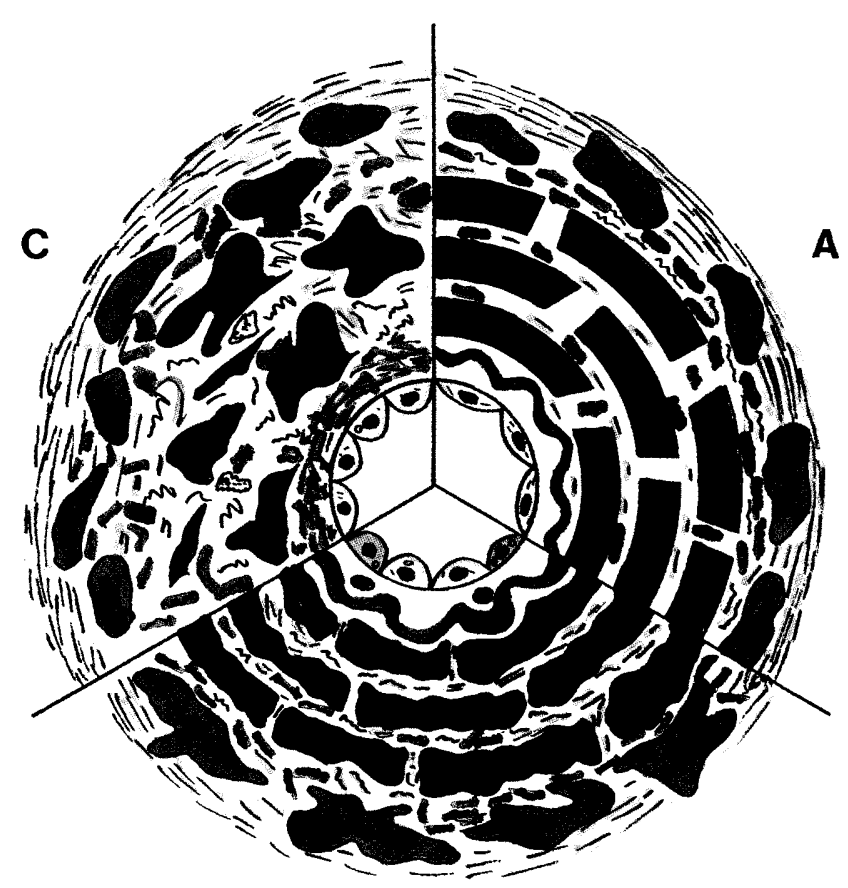

B

Fig. 3: Schematic drawing of arteriolar changes in relation to the number of foals delivered.

A After the first partus. The membrana elastica interna is enlarged and the peripheral media and the adventitia are thickened by deposition of collagen fibres arranged in bundles and a few elastic fibres occur.

B After the third partus. The membrana elastica interna is irregularly arranged and rich in mature elastic fibres. The media appears concentric but the myocytes have irregular contours and are intermingled with elastic fibres.

C After fifteen foalings. Within the whole vessel wall an accumulation of irregularly arranged, partially degenerated and mineralised fibres are visible. The myocytes are degenerated, atrophic or crippled with numerous intracytoplasmatic matrix vesicles.

red: myocytes; yellow-orange: endothelia, collagen fibres; green: membrana elastica interna, elastic fibres; light blue: mucopolysaccharides; pink: mineralisation

Schematische Darstellung von Veränderungen an Arteriolen in Abhängigkeit von der Anzahl der Abfohlungen.

A Nach der ersten Abfohlung. Elastische Fasern sind in der Membrana elastica interna zugebildet. Einzelne elastische und kollagene Fasern sind innerhalb der peripheren Media und Adventitia zu sehen.

B Nach der dritten Abfohlung. Die Membrana elastica interna ist durch Zubildung elastischer Fasern unregelmäßig verbreitert. Zwischen den konzentrisch angeordneten, jedoch teils degenerierten Myozyten sind elastische und kollagene Fasern eingelagert.

C Nach der fünfzehnten Abfohlung. Durch hochgradige Faserzubildung ist die gesamte Wand verbreitert, degenerierte und verkalkte Fasern kommen vor. Die Myozyten sind degeneriert oder atrophisch mit zahlreichen intrazytoplasmatischen Matrixvesikeln.

rot: Myozyten; gelb-orange: Endothelzellen, Kollagenfasern; grün: Membrana elastica interna, elastische Fasern; hellblau: Mukopolysaccharide; rosa: Verkalkungen.

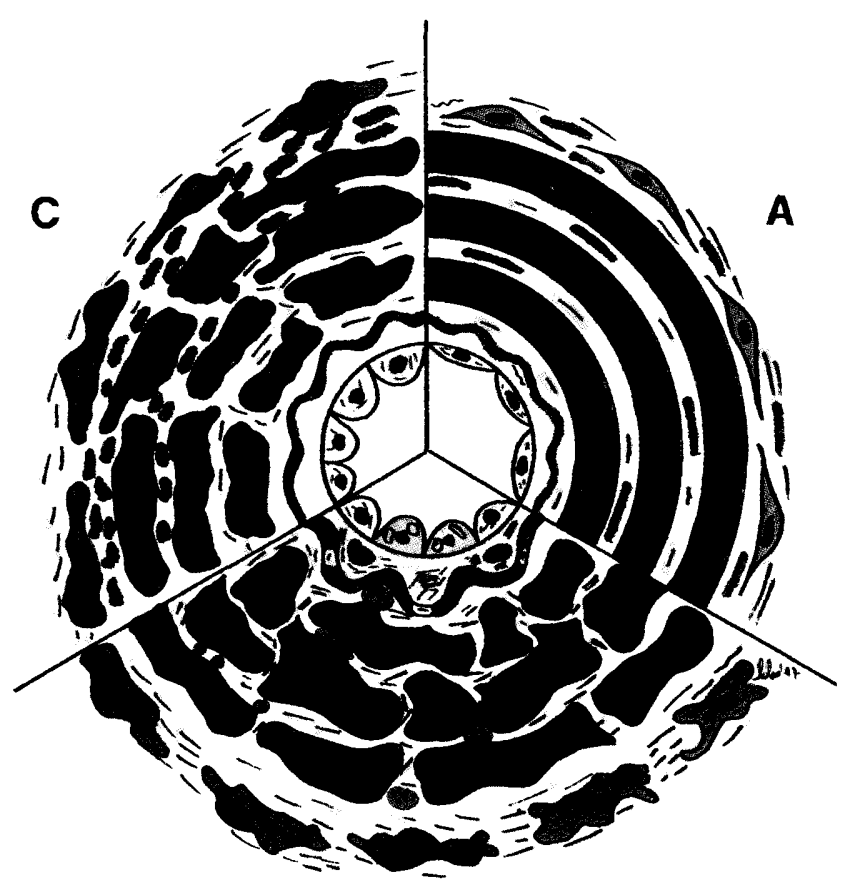

B

Fig. 4: Schematic drawing of the findings in an arteriole of a young mare before breeding and after her first foaling.

A Before the first breeding. The vessel wall shows a regular concentric composition of all histological structures: a uniform internal elastic membrane and only a few elastic fibres within the adventitia.

B Three days after the first partus. The media and intima are thickened, due to hyperplastic and sometimes degenerated myocytes and endothelia. The subendothelial clefts are widened and show deposits of mucopolysaccharides. The membrana elastica interna is spread with fine flakes of elastic fibres.

C Four weeks after the first partus. The findings in the intima and media have receded, but newly-constructed elastic fibres are obvious in the periphery of the media and adventitia.

red: myocytes; yellow-orange: endothelia, collagen fibres; green: membrana elastica interna, elastic fibres; light blue: mucopolysaccharides

Schematische Darstellung der Befunde in einer Arteriole bei einer jungen Stute vor und nach ihrer ersten Abfohlung.

A Vor der ersten Bedeckung. Das Gefäß zeigt einen regelmäßigen Wandaufbau mit einer fein gewellten Membrana elastica interna. Einzeine elastische Fasern kommen in der Adventitia vor.

B Drei Tage nach der ersten Abfohlung. Media und Intima sind verdickt durch hyperplastische und teilweise degenerierte Myozyten und Endothelien. Subendothelial sind Mukopolysaccharide abgelagert. Die Membrana elastica interna ist fragmentiert.

C Vier Wochen nach der ersten Abfohlung. Endothelzellen und Myozyten sind größtenteils regeneriert, in der peripheren Media und der Adventitia liegen neugebildete elastische Fasern vor.

rot: Myozyten; gelb-orange: Endothelzellen, Kollagenfasern; grün: Membrana elastica interna, elastische Fasern; hellblau: Mukopolysaccharide. 
To throw light on the pathogenesis of this condition Wrede (1999) obtained biopsies from maiden mares, uniparous and multiparous patients with several up to fifteen foalings. The first sample was taken before breeding, the second and third ones in the following year, three days and four weeks post partum.

In younger maiden mares the vessels show a regular concentric composition of all histological structures (Fig. 4-A): the basement membrane appears uniform, only a few collagen fibres are localised in the adventitia. Three days after the first partus (Fig. 4-B) the media and intima appear thickened, due to hyperplastic and sometimes degenerated myocytes and endothelia. The subendothelial clefts are widened and show deposits of mucopolysaccharides. The membrana elastica interna is spread with fine flakes of elastic fibres. During the following four weeks the involution of the endometrial vessels progresses (Fig. 4-C). The findings in the intima and media have receded. But already at this time, after the first foaling, newly-constructed collagen and elastic fibres are obvious in the periphery of the media, a perifibroelastosis has developed.

In comparison remodelling processes in a mare before and after the birth of her sixth foal are demonstrated in figure 5 . Before breeding (Fig. 5-A) the findings within the endometrial vessels can be characterised as a moderate to severe panelastosis. Three days post partum (Fig. 5-B) surprisingly the elastic fibres of the media have disappeared completely, except for very few between the media and adventitia. Four weeks later however (Fig. 5-C), a partially destructive panelastosis reappears, obviously more intense compared with the initial conditions.

\section{Clinical significance of angiopathies in relation to fertility}

With a view to pathogenesis, there are mainly three possible pathways leading from angiopathies to a reduced fertility:

- endometrial malperfusion in the course of insufficient arterial blood supply

- drainage disturbances caused by a reduced function of veins and lymphatic vessels

- complex functional impairment involving all types of vessels

\section{Insufficient arterial blood supply}

Insufficient arterial blood supply may be the reason for a reduced fertility in those mares showing an intact endometrium (category-l) but a severe angiosis, affecting the arterial system. Such patients have a lower foaling rate compared with other mares of category I exhibiting no or only slight angiopathies.

\section{Drainage disturbances}

Drainage disturbances are interpreted as the sequela of an impaired venous circulation. This results in secondary func-

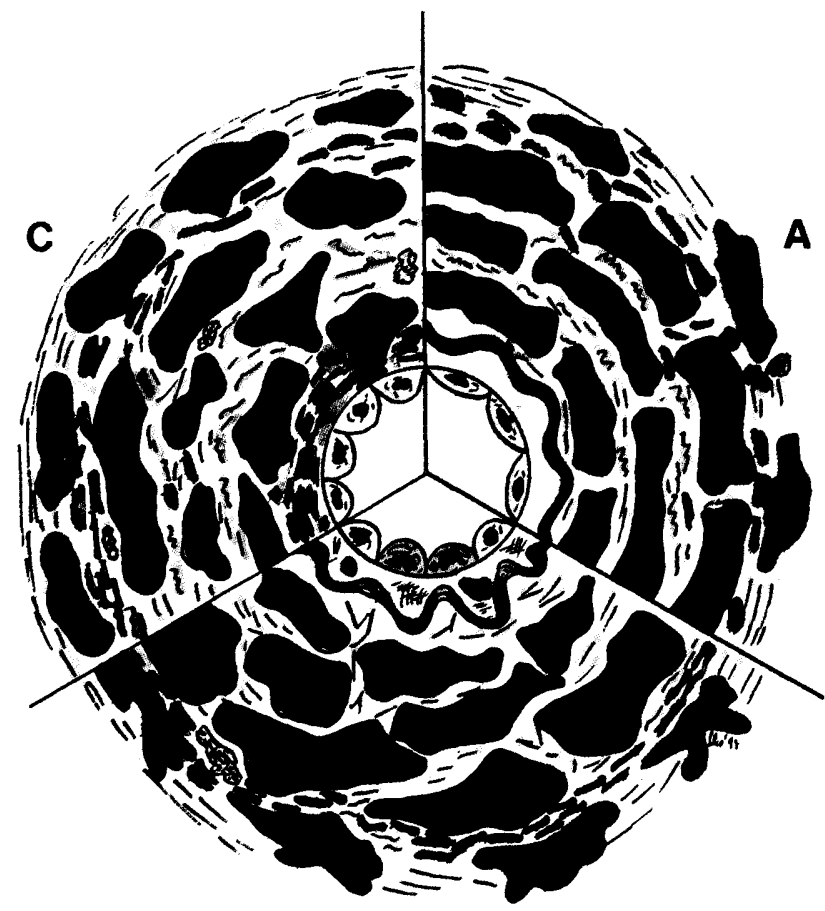

B

Fig. 5: Schematic drawing of the findings in an arteriole of a mare before and after her sixth foaling.

A Before breeding (after 5 previous foalings). A moderate panfibroelastosis is obvious.

B Three days after the sixth foaling. Degeneration processes within the intima and media and depositions of mucopolysaccharides are visible. The elastic fibres of the media have disappeared completely, except for very few ones between the media and adventitia.

C Four weeks after the sixth foaling. A partially destructive panfibroelastosis has reappeared, obviously more intense compared with the initial conditions.

red: myocytes; yeliow-orange: endothelia, collagen fibres; green: membrana elastica interna, elastic fibres; light blue: mucopolysaccharides; pink: mineralisation

Schematische Darstellung der Befunde in einer Arteriole bei einer Stute vor und nach ihrer sechsten Abfohlung.

A Vor der Bedeckung (nach der fünften Abfohlung). Die Arteriole zeigt ein mittelgradige Panfibroelastose.

B Drei Tage nach der sechsten Abfohlung. In der Intima und Media sind degenerative Prozesse sowie Mukopolysaccharidablagerungen sichtbar. Elastische Fasern sind bis auf einzelne Areale in der Adventitia nicht nachweisbar.

C Vier Wochen nach der sechsten Abfohlung. Eine partiell destruierende Panfibroelastose hat sich wieder entwickelt. Die Befunde sind offensichtlich gravierender als vor der Geburt.

rot: Myozyten; gelb-orange: Endothelzellen, Kollagenfasern; grün: Membrana elastica interna, elastische Fasern; hellblau: Mukopolysaccharide; rosa: Verkalkungen.

tional alterations of the lymphatic vessels, which are not primarily affected by morphological alterations within their walls. The consequences concern either the whole endometrium or only smaller areas.

Lymphangiectasia within the endometrium develops physiologically during the late pre-estrus, leading to the typical estrous edema of the uterus wall. The edema however 
disappears rapidly after ovulation, providing the drainagemechanisms are functionally intact. If not, the result is a pathological endometrial edema, morphologically characterised by persistent lymphangiectasia, occurring „out of phase". In most cases those mares show severe degenerative and partially obliterative phleboses. The pathogenesis is interpreted as indicative for an impaired endometrial drainage due to angioses. A complicating and supporting factor may be the dislocation of the uterus in older, multiparous mares.

Besides this, luminal or intramural cystic cavities, obvious in clinical examinations too, are secondary and local effects of a reduced endometrial drainage caused by phlebosis. Cavities, filled with fluid, may originate from different endometrial structures (Schoon et al., 1993): Smaller glandular cysts develop in the course of endometrosis and mainly greater ones result from local circulatory disturbances caused by phlebosclerosis. The definitive diagnosis of their origin in a certain case however requires histopathology.

Exceeding a certain diameter of the lymphatic-born cavities leads to the clinical diagnosis of so called "lymphatic lacunae". This term encloses two manifestations of lymphatic alterations (Schoon et al., 1993): larger, pathological lymphangiectasia, lined by a continuous or discontinuous endothelial layer, and extravascular accumulations of lymph fluid, so called lymphcysts (Fig. 6). Both features are to be interpreted as local sequelae of a destructive phlebosis. Especially older, multiparous mares are predisposed for those local findings.

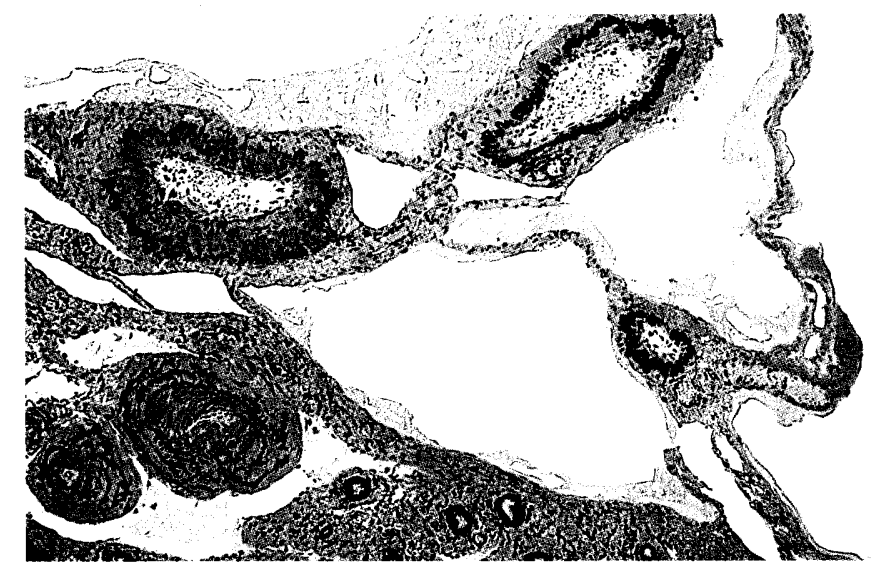

Fig. 6: Lymphcysts and Lymphangiectasia are associated with a severe fibroelastosis of arteries, arterioles and veins. Endometrial biopsy from a 13 year-old mare, 5 foalings. van Gieson-elastica stain, $x 120$

Lymphzysten und Lymphangiektasien sind vergesellschaftet mit einer hochgradigen Fibroelastose der Arterien, Arteriolen und Venen. Endometriumbiopsie einer 13 Jahre alten Stute, 5 Abfohlungen. Van Gieson-ElasticaFärbung, Gerätevergrößerung 120x

Endometrial cysts may hinder the migration of the conceptus in early pregnancy (Leidl et al., 1987). In affected mares a removal by endouterine surgery improves the pregnancy rate, though the treatment is only symptomatic (Bartmann et al., 1997). Varices accompany the lymphatic alterations or occur as incidental findings and are often located near the cervix (Schoon et al., 1993). The venous walls show more or less mostly severe degenerative alterations, predisposing these vessels for dilation.

\section{Complex functional impairment}

Possibly of the greatest functional importance are correlations between endometrosis and angioses. Based on own investigations dealing with the pathogenesis of both alterations (Schoon et al., 1997; Grüninger et al., 1998), it seems to be possible that at least one important reason for a progressing endometrosis may be a decreased endometrial perfusion and drainage. The correlations between incidence and degree of endometrosis on the one hand and the degree of vascular alterations on the other, are highly significant. These findings may support the proposal of Kenney (1992) to eliminate the term „chronic degenerative endometritis - CDE“ for characterising mainly fibrosing degenerative lesions of the equine endometrium.

\section{Prognosis}

Kriesten (1995) reports that angioses are not associated with significantly reduced foaling rates though she cannot exclude additional negative effects on fertility. But an indirect influence has to be considered: angioses may lead to a reduced endometrial drainage and perfusion and the morphologic vascular findings are closely related to the incidence of endometrosis. We conclude that these conditions should be taken into consideration when classifying endometrial biopsies with a view to prognosis.

Finally there seems to be a relationship between vascular lesions in endometrial, myometrial and extrauterine arteries (Schoon et al., unpublished data). In a concurrent study we are comparing incidence, type and degree of angiopathies detectable in biopsy samples to alterations obvious in the myometrium as well as in the uterine and utero-ovarian arteries. Fatal hemorrhages occurring during late pregnancy or at foaling result from rupture of major vessels. Older mares are especially predisposed to this condition. Histologically the lesions in ruptured vessels are described as a marked intimal fibroelastosis combined with a medial atrophy (Rooney and Robertson, 1996).

\section{Literature}

Bal, H.S. and R.. Getty (1971): Changes in the histomorphology of the uterus of the domestic pig (Sus scrofa domestica) with advancing age. J. Gerontol. 28, 160-172

Bartmann, C.P., A. Schöning, I. Brickwedel, B. Ohnesorge and E. Klug (1997): Hysteroskopie und minimal invasive endouterine Chirurgie bei der Stute. Pferdeheilkunde, 13, 474-482

Constantinescou, G. (1921): Beiträge zur Frage der Sterilitätsursachen bei den Stuten mit besonderer Berücksichtigung der histologischen Veränderungen des Uterus. Dissertation, Tierärztliche Hochschule Hannover

Goswamy, R.K., G. Williams and P.C. Steptoe (1988): Decreased uterine perfusion - a cause of infertility. Hum. Reprod. 3, 955-958 
Grüninger, B. (1996): Zur Pathogenese von Angiopathien im Endometrium der Stute - Morphologisch funktionelle Untersuchungen. Dissertation, Veterinärmedizinische Fakultät, Universität Leipzig

Grüninger, B., H.-A. Schoon, D. Schoon, S. Menger and E. Klug (1998): Incidence and morphology of endometrial angiopathies in mares in relationship to age and parity. J. comp. Path. 119, 293-309

Hard, D.L. and L.L. Anderson (1982): Interaction of maternal blood volume and uterine blood flow with porcine fetal development. Biol. Reprod. 27, 79-90

Kenney, R.M. (1992): The aetiology, diagnosis and classification of chronic degenerative endometritis. Proc. J. Hughes International Workshop on Endometritis, Equine vet. J. 25, 186

Kriesten, H. (1995): Zur prognostischen Bedeutung von Angiopathien im Rahmen der Kategorisierung von Endometriumsbiopsien bei Stuten. Dissertation, Tierärztliche Hochschule Hannover

Kriesten, H., D. Schoon and H.-A. Schoon (1996): Prognostic value of endometrial vascular changes within the categorizing of uterine biopsies of mares. Eur. J. Vet. Path. 2 Suppl., 18

Leidl, W., B. Kaspar and W. Kähn (1987): Endometriumzysten bei Stuten, Teil 2: Klinische Untersuchung, Vorkommen und Bedeutung. Tierärztl. Praxis 15, 281-289

Nambo, Y., M. Oikawa, T. Yoshihara, Y. Katayama and A. Kuwano (1994): Age-related morphometric changes in uterine wall arteries in mares. Biol. Reprod. 50 Suppl., 420

Nambo, Y., M. Oikawa, T. Yoshihara, A. Kuwano and Y. Katayama (1995): Age-related morphometric changes in uterine wall arteries in mares. J. Vet. Med. A 42, 383-387

Oikawa, M., Y. Katayama, T. Yoshihara, M. Kaneko and T. Yoshikawa (1993): Microscopic characteristics of uterine wall arteries in barren aged mares. J. comp. Path. 108, 411-415

Rahima, A. and A.L. Sodenwall (1977): Uterine collagen content in young and senescent pregnant golden hamsters. J. Reprod. Fertil. $49,161-162$
Rooney, J.R. and J.L. Robertson (1996): Equine Pathology. lowa State University Press, Ames, 237-238

Roperto, F. and P. Galati (1983): Arteriopatie uterine in bovine ipofertili. Acta med. vet. (Naples) 29, 17-22

Runge, A. (1995): Zur Repräsentanz histologischer Untersuchungsbefunde an Uterusbiopsien bei der Diagnose endometrial bedingter Fertilitätsstörungen der Stute. Dissertation, Veterinärmedizinische Fakultät, Universität Leipzig

Schoon, D., H. -A. Schoon and E. Klug (1994): Angiopathien im Endometrium der Stute. in: Dtsch. Vet. Med. Gesellschaft (Eds.): 13. Fachtagung der Fachgruppe Pferdekrankheiten DVG, Wiesbaden 1994, 17-29

Schoon, H.-A., D. Schoon, B. Ohnesorge and E. Klug (1993): Zur Diagnose, Pathogenese und Bedeutung endometrialer Zysten bei der Stute. Pferdeheilkunde 9, 215-221

Schoon, H.-A., D. Schoon and E. Klug (1997): Die Endometriumbiopsie bei der Stute im klinisch-gynäkologischen Kontext. Pferdeheilkunde 13, 453-464

Wrede, S. (1999): Zur Pathogenese der Graviditätssklerose an endometrialen Gefäßen der Stute. Dissertation, Veterinärmedizinische Fakultät, Universität Leipzig

Dr. Doris Schoon

Prof. Dr. H. -A. Schoon

Institut für Veterinär-Pathologie

An den Tierkliniken 33

04301 Leipzig

Tel. 0341/9738270

Fax. 0341/9738299

Schoon@rz.uni-leipzig.de

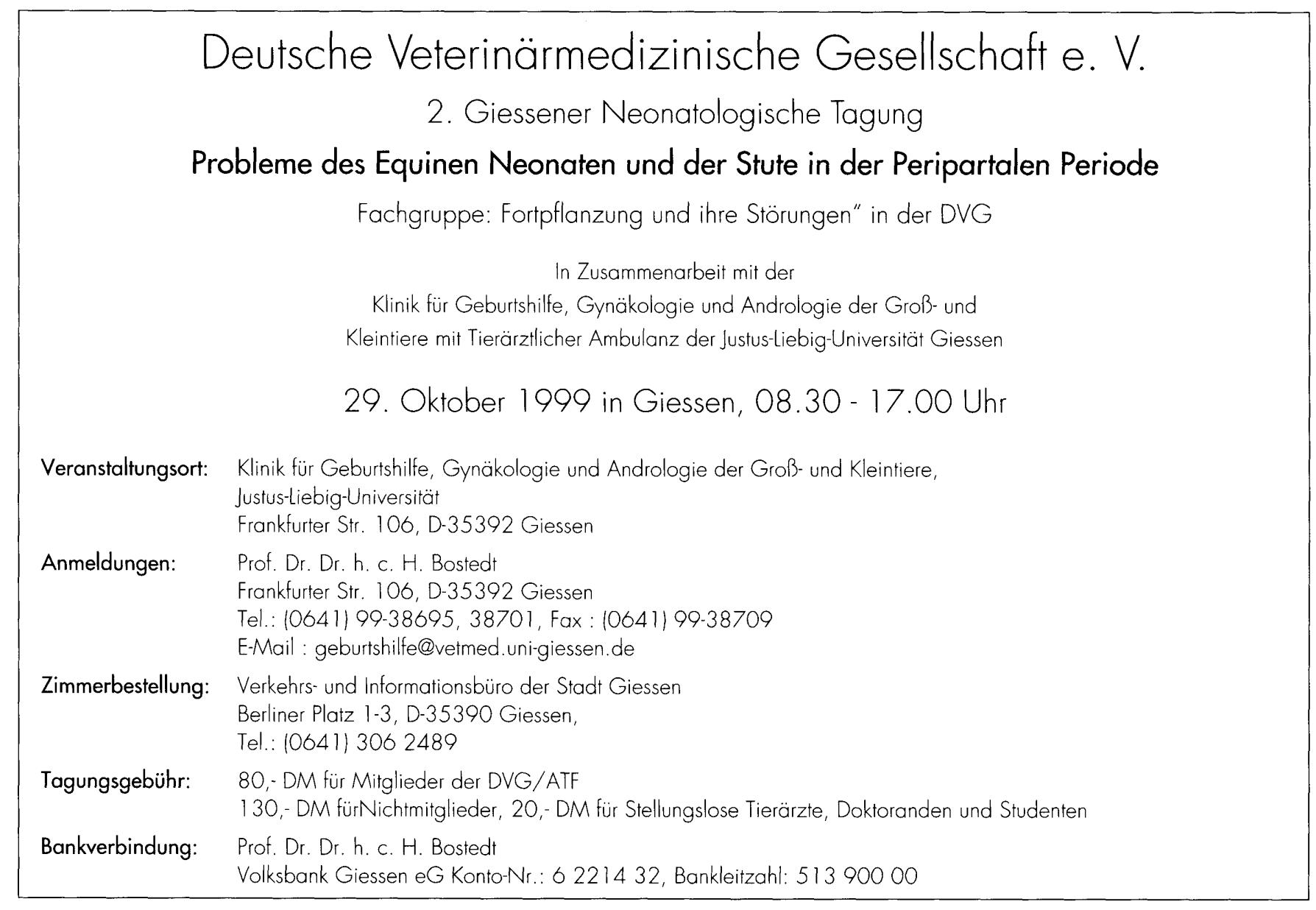

